\title{
Comparing Two Views of Motivation
}

\author{
David Palmer \\ School of Education, University of Newcastle, NSW 2308, Australia \\ Email: David.Palmer@newcastle.edu.au
}

\begin{abstract}
There is a need to clarify the nature of motivation because, in spite of much research on motivation, there are still widely divergent views about exactly what motivation is. For example, motivation can be viewed as either a short-term state or as a long-term predisposition. The purpose of the present paper is to critically compare these two conceptualizations with reference to the research literature and recent definitions. It was found that motivation should not be viewed as a long-term predisposition, or a collection of beliefs. Instead, it is argued that motivation should be viewed as a short-term state of mind that can be influenced by one's long-term predispositions.
\end{abstract}

Keywords: Motivation, self-efficacy, interest.

\section{Introduction}

Motivation is a fundamental construct in education, yet in many previous studies there has been little attempt to precisely define it. Murphy and Alexander (2000) reported that the word motivation was used in 51 of the studies in their paper, but was only explicitly defined on four occasions (8\%). Furthermore, authors such as Koballa and Glynn (2007), Pintrich and Schunk (2002) and Ramsden (1998) have noted that the term motivation has often been used with considerable overlap in meaning with other terms such as attitude, volition, self-regulation, interest, and curiosity. This lack of clarity is a serious problem for educationalists, as ambiguity can make it difficult to interpret findings in this field and to arrive at a consensus. The question of how the phenomenon of motivation should be conceptualized and defined is therefore important. The purpose of this paper is to compare two recent conceptualizations of motivation for learning.

\section{Recent Research on Motivation}

In recent years, much of the research on motivation has adopted the social cognitive perspective, which maintains that people tend to act in accordance with their own beliefs about their capabilities and the expected outcomes of their actions (Bandura, 1997). Self-efficacy (Bandura, 1981) is one of these beliefs, as students with high self-efficacy for a task will persist in their efforts until the task is completed, whereas those with low self-efficacy will tend to give up easily or even avoid the activity (Zimmerman, 2000). Consequently, there is strong relationship between self-efficacy, learning behaviors, and academic performance (Robbins et al., 2004). Expectancies and values concern students' judgments about their expectations of success as well as the potential usefulness of the content (Wigfield and Eccles, 1994, 2000). These can strongly influence learning and achievement, as people tend to choose tasks for which they have a high expectation of success and they are more likely to persist at tasks that they consider valuable (Eccles, 2009). Attributions are beliefs about the factors that have caused past successes or failures, and they are important because they may influence students' learning behaviors and performance in future tasks (Perry, Stupnisky, Daniels, and Haynes, 2008; Weiner, 1986, 2010; Yates, 2002).

In addition to beliefs, there are other types of predispositions that are also important. Long-term individual interest (Hidi, 1990) can strongly influence learning behaviors and achievement, as a student with an individual interest in music for example will seek out music-related experiences and while so engaged will experience enjoyment and increased knowledge (Ainley, Hidi, and Berndorff, 2002). Achievement goals are the purposes that students have for engaging in learning tasks (Ames, 1992; Kaplan and Maehr 1999; Mansfield, 2010; Pintrich, 2000a). Students with mastery goals for example, 
have a focus on learning or mastering the concepts, so these students are more likely to demonstrate deep learning strategies, persistence, effort, and enhanced performance (Anderman and Maehr, 1994; Pintrich 2000b; Roussel, Elliot, and Feltman, 2011; Xiang, McBride, and Solmon, 2003). Finally, psychological needs for competence, autonomy, and social relatedness have been found to have a significant effect on student learning behaviors and achievement, and the construct of intrinsic motivation has been used to refer to this phenomenon (Black and Deci, 2000; Hanze and Berger, 2007; Niemiec and Ryan, 2009).

The importance of the factors above is well-established, but there are other factors that can, on occasion, have powerful negative effects on student motivation. Strong negative emotions such as anger, sadness, fear, or boredom can influence the extent to which students are willing to become involved in learning (Girod, Pardales, Cavanaugh, and Wadsworth, 2005; Pintrich and Schunk, 2002). Basic physical needs can also profoundly affect learning behaviors because if students are hungry, thirsty, tired, in danger, discomfort, or in poor health it is less likely that they will be able to learn (Edens, 2006; Kim and Song, 2010; Pintrich and Schunk, 2002). Even more significantly, factors such as fatigue and hunger can, on occasion, completely preclude all learning behaviors (Schunk, 2004). This is a very important point which is critical to the arguments presented in this paper.

Factors external to the individual are also known to influence learning behaviors and achievement, and a wide range of these have been identified. These include teacher enthusiasm (Brigham, Scruggs, and Mastropieri, 1992), use of humor (Fisher, 1997), pedagogical techniques such as inquiry activities (Hofstein and Lunetta, 2004), and real world relevance (Zusho, Pintrich, and Coppola, 2003). Some external factors can have positive or negative effects depending on the situation: overuse of specific pedagogical techniques has been linked to boredom and cessation of learning behaviors (Mann and Robinson, 2009); the effects of peers can be positive when they value learning, but can be negative when classmates are resistant to school norms (Nelson and DeBacker, 2008); and extrinsic inducements such as rewards, praise, privileges, and attention can have complex effects that are not always easy to predict (Corpus, McClintic-Gilbert, and Hayenga, 2009; Deci, Koestner, and Ryan, 2001; Gottfried, Marcoulides, Gottfried, and Oliver, 2009). Finally, distractions and interruptions can have negative effects on student learning behaviors (Anthony, 2009; Harrison, 1983).

In summary, motivation can be influenced by a wide variety of internal and external factors. However, it is still very difficult to tell from this research exactly what motivation for learning actually is. Thus, the problem of conceptualizing the phenomenon still remains. In the following section, two common views of motivation will be examined towards resolving this issue.

\section{Two Views of Motivation}

Previous authors have variously viewed motivation as a short-term state and/or a long-term predisposition. Brophy (1998) for example, stated that student motivation to learn can be viewed either as a situation-specific state, or as a general disposition. The situation specific state would occur in a particular situation when a student feels motivated and immediately engages in learning. On the other hand, the general disposition is an enduring tendency to value learning. These views have been echoed by more recent authors. For example Green (2002) defined motivation as a state: "Motivation is typically defined as an internal state that activates, guides, and maintains behavior" (p. 989). However, Martin and Dowson (2009) emphasized the long-term beliefs: "Motivation is defined as a set of interrelated beliefs and emotions that influence and direct behavior" (p. 328).

It is important to emphasize one commonality between these two definitions. Both suggest that motivation results in behavior. Similarly, Ford (1992) argued that motivation had three roles: to activate behavior, to direct behavior, and to regulate the persistence of behavior. Thus, for the purposes of this paper, motivation for learning will be taken to be the phenomenon that activates learning behavior. Learning behaviors can include the physically observable behaviors such as looking at the teacher, beginning work on a task, following directions, completing work, volunteering answers, asking for help, and asking questions (Stipek, 2002). Other learning behaviors might not be physically observable and these, including focusing attention, recalling, comparing, analyzing, and reflecting, have been referred to as cognitive learning behaviors (e.g., Furinghetti and Morselli, 2009; Ulmer and Torres, 2007). 
Achievement has sometimes been used as an indicator of motivation (Pintrich and Schunk, 2002) but there is only an indirect relationship between the two. As noted above, the definitions of motivation suggest that it results only in the activation of learning behaviors. This does not necessarily result in achievement/learning because other factors can affect the amount of learning that occurs. For example, students vary in their ability to perform specific learning behaviors such as recalling, analyzing, reflecting, and comparing (e.g., Lau and Roeser, 2002), so this will impact on the amount and quality of learning. In addition, learning and achievement will be partly influenced by pedagogical factors such as the clarity of the explanations provided by the teacher (Rodger, Murray, and Cummings, 2007). Thus, according to the decision-making model, the process of motivation itself would not guarantee how much learning will occur or that a student will learn what the teacher intended; it just means that motivation would ensure that students are trying to learn, by activating learning behaviors such as focusing attention and thinking.

In the following sections, the two views of motivation will be analyzed.

\section{Is Motivation a Long-term Predisposition Involving One's Beliefs?}

The question of whether motivation should be viewed as a long-term phenomenon is an important one because a large body of research has shown that long-term beliefs about self-efficacy, attributions, expectancies and values, as well as achievement goals and individual interests, can play powerful roles in influencing learning behavior.

However, in this section it will be argued that motivation should not be regarded as a long-term predisposition, a belief, or an interrelated set of beliefs. As stated above, the definitions of motivation have suggested that motivation is the phenomenon that activates learning behavior. However, long-term predispositions or beliefs do not directly activate behavior. Schunk (2004) noted that there can be occasions on which hunger and fatigue can completely prevent learning behaviors. This implies that a student might have an enduring predisposition to value learning, but if that student comes to school fatigued or hungry then he/she may or may not display learning behaviors. The idea that fatigue and hunger can override a predisposition suggests there can be times when other factors can interfere to prevent that predisposition from having an effect. This means that a predisposition is not a direct determinant of behavior, so it cannot be motivation.

The same reasoning applies to each of the other long-term beliefs, goals, interests, and values that students might have: Fatigue and hunger can, on occasion, prevent all learning behaviors (Schunk, 2004), which implies that the effects of any particular belief can be nullified under certain conditions. Physical states such as fatigue and hunger are not the only factors that can have this effect, as it has been found that a range of other internal and external factors can preclude or moderate the effects of particular beliefs: (1) low levels of individual interest can be overridden by highly interesting classroom activities (Flowerday, Schraw, and Stevens, 2004) and conversely, high levels of individual interest can be overridden by repetitive pedagogy (Mann and Robinson, 2009); (2) the negative effects of less desirable attributions can be overridden by high quality teaching (Perry and Magnusson, 1989); (3) the effects of attributions depend on other cognitions that make up the student's learning model (Ferla, Valke, and Schuyten, 2009); (4) the effects of expectancies are dependent on task value (Wigfield and Eccles, 1994) and the effects of task value can be mediated by achievement goals (Lau, Liem, and Nie, 2008); (5) the effects of achievement goals can be mediated by negative emotions such as boredom, sadness, or fear (Pekrun, Elliot, and Maier, 2009; Pintrich and Schunk, 2002); and finally (6) the effects of self-efficacy can be mediated by interests (Lent, Lopez, and Bieschke, 1991), attributions (Wilson and Trainin, 2007), and achievement goals (Lau et al., 2008). Thus, individual beliefs, values, or interests are not direct determinants of behavior, as other factors can interfere to either nullify or modify the effects of each one. Motivation is the phenomenon that directly activates behavior so if a belief does not directly activate behavior then it cannot be motivation.

Neither should motivation be viewed as a collection of beliefs nor the sum total of the interrelationships between one's beliefs, achievement goals, values, and interests. For example, a student might theoretically have a complete set of fully positive beliefs, interests, and values for learning in mathematics, but there may still be a mathematics lesson in which that student is too hungry or too 
tired to concentrate and think. Thus, an interrelated collection of beliefs does not have the ability to directly activate behavior, so it cannot be motivation.

\section{$5 \quad$ Is Motivation a Short-Term State of Mind?}

The alternative view is that motivation might be regarded as a short-term state of mind. This transient state of motivation, as when one becomes "motivated" in a particular situation and immediately engages in a learning activity, is an intuitively appealing idea because at these times individuals commonly experience an identifiable feeling. This feeling has been described as curiosity (Niemiec and Ryan, 2009), readiness to learn and explore (Ryan and Deci, 2000), wanting to make sense of things (Wlodkowski, 1999), a desire to know more (Maw and Maw, 1964, as cited in Rotto, 1994), or a desire to engage (Schunk, 2004). These feelings can collectively be referred to as states because they tend to dominate our consciousness when they occur, yet they do not persist for extended periods.

Importantly, there is substantial evidence suggesting that this state is typically accompanied by learning behaviors. For example, Maw and Maw (1964) stated that curiosity was characterized by people "reacting positively to new, strange, incongruous, or mysterious elements in their environment by moving toward them, exploring them or manipulating them" (Rotto, 1994, p. 31). In other words, when we experience the state of curiosity in a particular situation, learning behaviors occur. In addition, Niemiec and Ryan (2009) noted that learning behaviors associated with intrinsic motivation were accompanied by feelings of curiosity and interest; and Hidi and Anderson (1992) stated that student engagement in cognitive activities was accompanied by a positive feeling "to find out more about it" (p. 219). Thus, this state of mind comprising an urge to learn, is typically accompanied by learning behaviors.

Thus, there are good reasons to believe that the active state of motivation is most directly associated with learning behaviors. In fact, the two can usually occur concurrently when one is engaged in learning.

\section{Conclusion and Implications}

The purpose of this paper was to compare two conceptualizations of motivation. It was found that one of these, the view of motivation as an active state of mind, was to be preferred. Accordingly, an appropriate definition would be,

Motivation for learning is an active state of mind that can occur on particular occasions

and which produces the activation of learning behaviors.

In this definition, the state of mind is a strong urge to learn, so it includes situated feelings of curiosity, wanting to understand, or wanting to find out, which are aroused in a particular context. It is almost certainly influenced by one's beliefs, values, interests, psychological needs, physical needs, emotions, peers, teacher enthusiasm, extrinsic inducements, pedagogical techniques, interruptions, and distractions. The learning behaviors include a wide range of specific cognitive behaviors such as focusing attention, planning, recalling, comparing, imagery, self-instruction, analyzing, and reflecting, as well as physically observable behaviors such as looking at the teacher and asking questions.

The main implication for future research is that in order to study motivation it is necessary to study it as a short-term state rather than a long-term phenomenon. This has implications for research because much of the data gathered to date has been done by large-scale surveys which are usually not carried out when students are actually experiencing motivation to learn. These types of surveys are popular with researchers however, because they typically deal with relatively stable beliefs and values, so they can be implemented at any time. Consequently, much is known about the influence of these beliefs. The challenge for future research will be to balance this with in situ studies at times when students are currently experiencing a state of motivation.

There is also an important implication for teaching. If motivation is a short-term state then learning behaviors may be activated or de-activated at any time throughout a lesson. Teachers should be aware that even when learning behaviors are happening they can be de-activated prematurely by interruptions or other changes in internal or external factors. It is not enough to provide a single engaging experience at the beginning of a lesson and assume that its effects will continue until learning has been completed. 
The teacher must instead aim to ensure that optimal conditions for the ongoing activation of the state of motivation are maintained at all stages of the lesson.

Finally, it is crucially important that we continue to develop our understanding of motivation. Many adolescent students have motivation-related problems in school, and these will not be resolved unless very clear directions for action can be derived from research. It is therefore crucial that we continue to work towards a shared understanding of what motivation actually is.

\section{References}

1. Ainley, M., Hidi, S., \& Berndorff, D. (2002). Interest, learning, and the psychological processes that mediate their relationship. Journal of Educational Psychology, 94, 545-561. doi:10.1037//0022-0663.94.3.545.

2. Ames, C. (1992). Classrooms: Goals, structures, and student motivation. Journal of Educational Psychology, 84, 261-271. doi:10.1037/0022-0663.84.3.261.

3. Anderman, E. M., \& Maehr, M. L. (1994). Motivation and schooling in the middle grades. Paper of Educational Research, 64, 287-309. doi:10.2307/1170696.

4. Anthony, K. V. (2009). Educational counter culture: Motivations, instructional approaches, curriculum choices, and challenges of home school families (Doctoral dissertation). Available from Educational Resources Information Center. (ED510042).

5. Bandura, A. (1981). Self-referent thought: A developmental analysis of self-efficacy. In J. H. Flavell and L. Ross (Eds.), Social cognitive development: Frontiers and possible futures (pp. 200-239). New York, NY: Cambridge University Press.

6. Bandura, A. (1997). Self-efficacy: The exercise of control. New York, NY: W.H. Freeman and Co.

7. Black, A. E., \& Deci, E. L. (2000). The effects of instructors' autonomy support and students' autonomous motivation on learning organic chemistry: A self-determination theory perspective. Science Education, 84, 740756. doi:10.1002/1098-237X(200011)84:6<740::AID-SCE4>3.0.CO;2-3.

8. Brigham, F. J., Scruggs, T. E., \& Mastropieri, M. A. (1992). Teacher enthusiasm in learning disabilities classrooms: Effects on learning and behavior. Learning Disabilities Research and Practice, 7, 68-73.

9. Brophy, J. (1998). Motivating students to learn. Boston, MA: McGraw Hill.

10.Corpus, J. H., McClintic-Gilbert, M. S., \& Hayenga, A. O. (2009). Within-year changes in children's intrinsic and extrinsic motivational orientations: Contextual predictors and academic outcomes. Contemporary Educational Psychology, 34, 154-166. doi:10.1016/j.cedpsych.2009.01.001.

11.Deci, E. L., Koestner, R., \& Ryan, R. M. (2001). Extrinsic rewards and intrinsic motivation in education: Reconsidered once again. Paper of Educational Research, 71, 1-27. doi:10.3102/00346543071001001.

12.Eccles, J. (2009). Who am I and what am I going to do with my life? Personal and collective identities as motivators of action. Educational Psychologist, 44, 78-89. doi:10.1080/00461520902832368

13.Edens, K. M. (2006). The relationship between university students' sleep habits and academic motivation. NASPA Journal, 43, 432-445.

14.Ferla, J., Valcke, M., \& Schuyten, G. (2009). Student models of learning and their impact on study strategies. Studies in Higher Education, 34, 185-202. doi:10.1080/03075070802528288.

15.Fisher, M. S. (1997). The effect of humor on learning in a planetarium. Science Education, 81, 703-713. doi:10.1002/(SICI)1098-237X(199711)81:6<703::AID-SCE7>3.0.CO;2-M.

16.Flowerday, T., Schraw, G., \& Stevens, J. (2004). The role of choice and interest in reader engagement. The Journal of Experimental Education, 72, 93-115. doi:10.3200/JEXE.72.2.93-114.

17.Ford, M. E. (1992). Motivating humans: Goals, emotions and personal agency beliefs. Newbury Park, CA: Sage.

18.Furinghetti, F., \& Morselli, F. (2009). Every unsuccessful problem solver is unsuccessful in his or her own way: Affective and cognitive factors in proving. Educational Studies in Mathematics, 70, 71-90. doi:10.1007/s10649008-9134-4.

19.Girod, M., Pardales, M., Cavanaugh, S., \& Wadsworth, P. (2005). By teens, for teachers: A descriptive study of adolescence. American Secondary Education, 33, 4-20.

20.Gottfried, A. E., Marcoulides, G. A., Gottfried, A. W., \& Oliver, P. H. (2009). A latent curve model of parental motivational practices and developmental decline in math and science academic intrinsic motivation. Journal of Educational Psychology, 101, 729-739. doi:10.1037/a0015084. 
21.Green, S. K. (2002). Using an expectancy-value approach to examine teachers' motivational strategies. Teaching and Teacher Education, 18, 989-1005. doi:10.1016/S0742-051X(02)00055-0

22.Hanze, M., \& Berger, R. (2007). Cooperative learning, motivational effects, and student characteristics: An experimental study comparing cooperative learning and direct instruction in 12th grade physics classes. Learning and Instruction, 17, 29-41.

23.Harrison, R. (1983, April). A descriptive study of the perceived influence of institutional interruptions on the morale and work of teachers and pupils in elementary schools. Paper presented at the annual meeting of the American Educational Research Association, Montreal, Canada.

24.Hidi, S. (1990). Interest and its contribution as a mental resource for learning. Paper of Educational Research, 60, 549-571. doi:10.3102/00346543060004549

25.Hidi, S., \& Anderson, V. (1992). Situational interest and its impact on reading and expository writing. In K. A. Renninger, S. Hidi and A. Krapp (Eds.), The role of interest in learning and development (pp. 215-238). Hillsdale, NJ: Lawrence Erlbaum.

26. Hofstein, A., \& Lunetta, V. N. (2004). The laboratory in science education: Foundations for the Twenty-First Century. Science Education, 88, 28-54. doi.10.1002/sce.10106

27.Kaplan, A., \& Maehr, M. L. (1999). Enhancing the motivation of African American students: An achievement goal theory perspective. The Journal of Negro Education, 68, 23-42. doi:10.2307/2668207

28.Kim, M., \& Song, J. (2010, July). Learning fatigue in a science museum and a science classroom. Paper presented at the annual conference of the Australasian Science Education Research Association, Port Stephens, NSW.

29.Koballa T. R. Jr., \& Glynn, S. M. (2007). Attitudinal and motivational constructs in science learning. In S. K. Abell and N. G. Lederman (Eds.), Handbook of research on science education (pp. 75-102). New York, NY: Routledge.

30.Lau, S., Liem, A. D., \& Nie, Y. (2008). Task- and self-related pathways to deep achievement goals, classroom attentiveness, and group participation. British Journal of Educational Psychology, 78, 639-662. doi:10.1348/000709907X270261

31.Lau, S., \& Roeser, R. W. (2002). Cognitive abilities and motivational processes in high school students' situational engagement and achievement in science. Educational Assessment, 8, 139-162. doi:10.1207/S15326977EA0802_04.

32.Lent, R. W., Lopez, F. G., \& Bieschke, K. J. (1991). Mathematics self-efficacy: Sources and relation to sciencebased career choice. Journal of Counseling Psychology, 38, 424-430. doi:10.1037/0022-0167.38.4.424.

33.Mann, S., \& Robinson, A. (2009). Boredom in the lecture theatre: An investigation into the contributors, moderators and outcomes of boredom amongst university students. British Educational Research Journal, 35, 243-258. doi:10.1080/01411920802042911.

34.Mansfield, C. F. (2010). Motivating adolescents: Goals for Australian students in secondary schools. Australian Journal of Educational and Developmental Psychology, 10, 44-55.

35.Martin, A. J., \& Dowson, M. (2009). Interpersonal relationships, motivation, engagement, and achievement: Yields for theory, current issues, and educational practice. Paper of Educational Research, 79, 327-365. doi:10.3102/0034654308325583.

36.Maw, W. H., \& Maw, E. W. (1964). An exploratory study into the measurement of curiosity in elementary school children. Washington, DC: Department of Health, Education and Welfare.

37.Murphy, P. K., \& Alexander, P. A. (2000). A motivated exploration of motivation terminology. Contemporary Educational Psychology, 25, 3-53. doi:10.1016/ceps.1999.1019.

38.Nelson, R. M., \& DeBacker, T. K. (2008). Achievement motivation in adolescents: The role of peer climate and best friends. The Journal of Experimental Education, 76, 170-188. doi:10.3200/JEXE.76.2.170-190.

39.Niemiec, C. P., \& Ryan, R. M. (2009). Autonomy, competence, and relatedness in the classroom: Applying selfdetermination theory to educational practice. Theory and Research in Education, 7, 133-144. doi: $10.1177 / 1477878509104318$.

40.Pekrun, R., Elliot, A. J., \& Maier, M. A. (2009). Achievement goals and achievement emotions: Testing a model of their joint relations with academic performance. Journal of Educational Psychology, 101, 115-135. doi:10.1037/a0013383. 
41.Perry, R. P., \& Magnusson, J. -L. (1989). Causal attributions and perceived performance: Consequences for college students' achievement and perceived control in different instructional conditions. Journal of Educational Psychology, 81, 164-172. doi:10.1037/0022-0663.81.2.164.

42.Perry, R. P., Stupnisky, R. H., Daniels, L. M., \& Haynes, T. L. (2008). Attributional (explanatory) thinking about failure in new achievement settings. European Journal of Psychology of Education, 23, 459-475. doi:10.1007/BF03172753.

43.Pintrich, P. R. (2000a). An achievement goal theory perspective on issues in motivation terminology, theory and research. Contemporary Educational Psychology, 25, 92-104. doi:10.1006/ceps.1999.1017.

44.Pintrich, P. R. (2000b). Multiple goals, multiple pathways: The role of goal orientation in learning and achievement. Journal of Educational Psychology, 92, 544-555. doi:10.1037/0022-0663.92.3.544

45.Pintrich, P. R., \& Schunk, D. H. (2002). Motivation in education: Theory, research and applications. Englewood Cliffs, NJ: Prentice-Hall.

46.Ramsden, J. M. (1998). Mission impossible? Can anything be done about attitudes to science? International Journal of Science Education, 20, 125-137. doi:10.1080/0950069980200201.

47.Robbins, S. B., Lauver, K., Le, H., Davis, D., Langley, R., \& Carlstrom, A. (2004). Do psychosocial and study skill factors predict college outcomes? A meta-analysis. Psychological Bulletin, 130, 261-288. doi:10.1037/00332909.130.2.261.

48. Rodger, S., Murray, H. G., \& Cummings, A. L. (2007). Effects of teacher clarity and student anxiety on student outcomes. Teaching in Higher Education, 12, 91-104. doi:10.1080/13562510601102255

49.Rotto, L. J. (1994, February). Curiosity, motivation, and "flow" in computer-based instruction. Proceedings of selected research and development presentations at the 1994 national convention of the Association for Educational Communications and Technology Sponsored by the Research and Theory Division, Nashville, TN. (ED373755)

50.Roussel, P., Elliot, A. J., \& Feltman, R. (2011). The influence of achievement goals and social goals on helpseeking from peers in an academic context. Learning and Instruction, 21, 394-402. doi.10.1016/j.learninstruc.2010.05.003.

51.Ryan, R. M., \& Deci, E. L. (2000). Intrinsic and extrinsic motivations: Classic definitions and new directions. Contemporary Educational Psychology, 25, 54-67. doi:10.1006/ceps.1999.1020.

52.Schunk, D. H. (2004). Learning theories: An educational perspective. Upper Saddle River, NJ: Pearson Prentice Hall..

53.Stipek, D. (2002). Motivation to learn: Integrating theory and practice (4th ed.). Boston, MA: Allyn and Bacon.

54.Ulmer, J. D., \& Torres, R. M. (2007). A comparison of the cognitive behaviors exhibited by secondary agriculture and science teachers. Journal of Agricultural Education, 48, 106-116. doi:10.5032/jae.2007.04106

55.Weiner, B. (1986). An attributional theory of motivation and emotion. New York, NY: Springer-Verlag..

56.Weiner, B. (2010). The development of an attribution-based theory of motivation: A history of ideas. Educational Psychologist, 45, 28-36. doi:10.1080/00461520903433596.

57.Wigfield, A., \& Eccles, J. S. (1994). Children's competence beliefs, achievement values, and general self-esteem: Change across elementary and middle school. Journal of Early Adolescence, 14, 107-137. doi:10.1177/027243169401400203.

58.Wigfield, A., \& Eccles, J. S. (2000). Expectancy-value theory of achievement motivation. Contemporary Educational Psychology, 25, 68-81. doi:10.1006/ceps.1999.1015.

59.Wilson, K. M., \& Trainin, G. H. (2007). First-grade students' motivation and achievement for reading, writing and spelling. Reading Psychology, 28, 257-282. doi:10.1080/02702710601186464

60.Wlodkowski, R. J. (1999). Enhancing adult motivation to learn. San Francisco, CA: Jossey-Bass.

61.Xiang, P., McBride, R., \& Solmon, M. A. (2003). Motivational climates in ten teachers' elementary physical education classes: An achievement goal theory approach. The Elementary School Journal, 104, 71-92. doi:10.1086/499743.

62.Yates, S. M. (2002). The influence of optimism and pessimism on student achievement in mathematics. Mathematics Education Research Journal, 14, 4-15. doi:10.1007/BF03217113

63.Zimmerman, B. J. (2000). Attaining self-regulation: A social cognitive perspective. In M. Boekaerts, P. R. Pintrich, and M. Zeichner (Eds.), Handbook of self-regulation (pp. 13-39). San Diego, CA: Academic Press.. 
64.Zusho A., Pintrich, P. R., \& Coppola, B. (2003). Skill and will: The role of motivation and cognition in the learning of college chemistry. International Journal of Science Education, 25, 1081-1094. doi:10.1080/0950069032000052207. 